\title{
ECONOMIC DEVELOPMENT An Introduction
}


Macmillan International College Editions (MICE) are authoritative paperback books covering the history and cultures of the developing world, and its scientific, technical, social and economic development. The MICE programme contains many distinguished series in a wide range of disciplines, some titles being regionally biassed, others more international. Library editions will usually be published simultaneously with the paperback editions.

Other related titles

Aziz Rural Development-Learning from China

FitzGerald Public Sector Investment Planning for Developing Countries

Wong ASEAN Economies in Perspective

Forthcoming titles

Nwankwo Nigerian Financial System

Olaloku Structure of the Nigerian Economy

Ghatak Monetary Economics in Developing Countries 

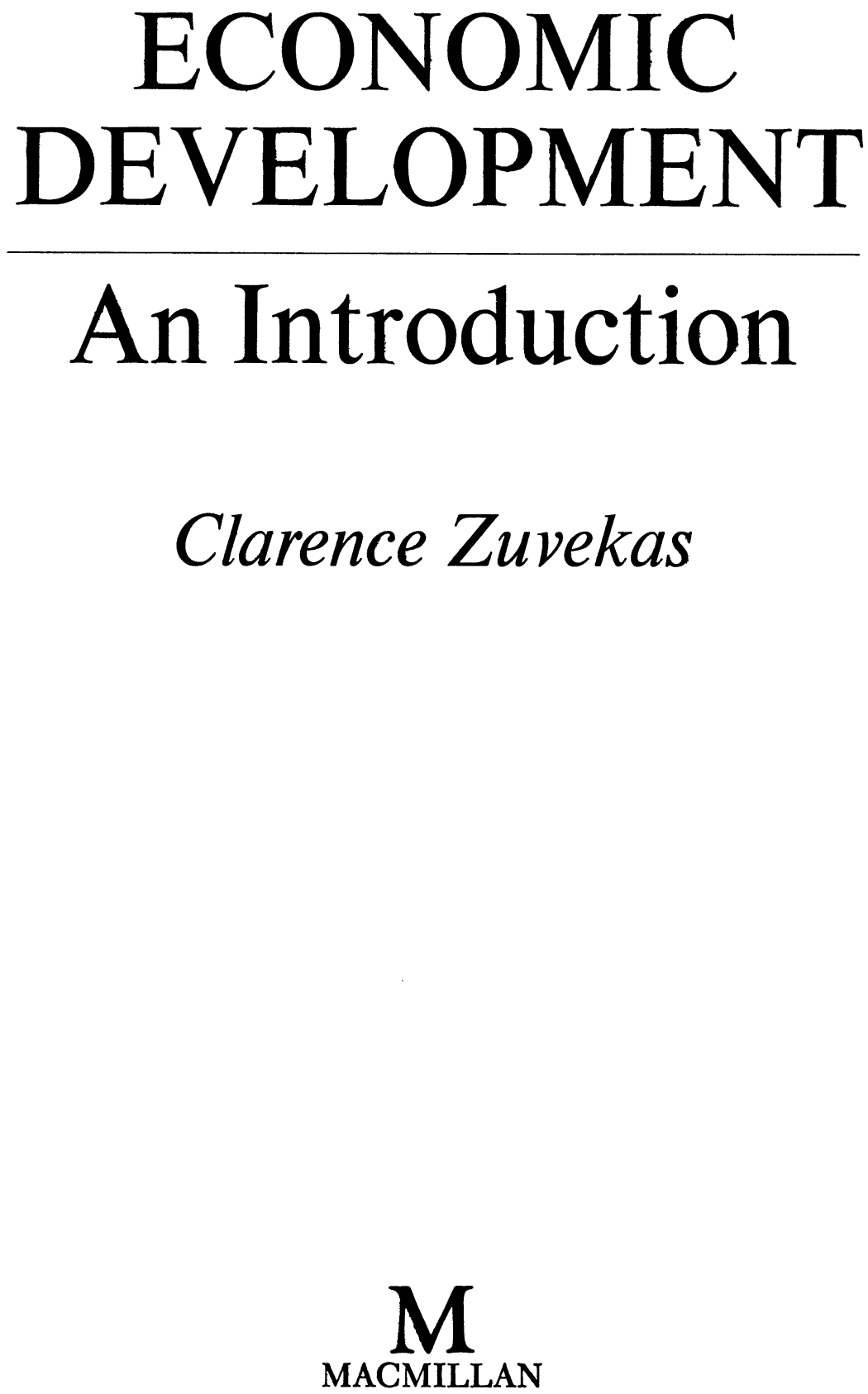


\title{
TO ANN
}

(C) C. Zuvekas 1979

All rights reserved. No part of this publication may be reproduced or transmitted, in any form or by any means, without permission.

\author{
First published by \\ THE MACMILLAN PRESS LTD \\ London and Basingstoke \\ Associated companies in Delhi Dublin \\ Hong Kong Johannesburg Lagos Melbourne \\ New York Singapore and Tokyo
}

\author{
British Library Cataloguing in Publication Data \\ Zuvekas, Clarence \\ Economic development. \\ 1. Economic development \\ I. Title \\ $330.9 \quad$ HD82 \\ ISBN 978-0-333-27648-8 ISBN 978-1-349-16275-8 (eBook) \\ DOI 10.1007/978-1-349-16275-8
}

This book is sold subject to the standard conditions of the Net Book Agreement.

The paperback edition of this book is sold subject to the condition that it shall not, by way of trade or otherwise, be lent, re-sold, hired out, or otherwise circulated without the publisher's prior consent in any form of binding other than that in which it is published and without a similar condition including this condition being imposed on the subsequent purchaser. 


\section{Preface}

This textbook treats economic development as an interdisciplinary subject and is designed specifically for courses in which many students may not be economics majors. Its focus thus differs from that of the several goodto-excellent texts aimed at advanced undergraduate and graduate students in economics. Still, it is written from an economist's perspective, with no attempt at any "grand synthesis" of the social sciences.

Coverage of the subject matter is fairly comprehensive but certainly not exhaustive. Space considerations dictate that some topics be treated only briefly, and this results inevitably in generalizations with which I myself am sometimes uncomfortable. However, students should not have to wade through qualifications and exceptions to every statement. For those who wish to explore certain topics in more detail, the annotated references at the end of each chapter provide a guide to studies that can be read without great difficulty. These references are selective because important works on the subject now run into the thousands. The compactness of the text should afford instructors considerable flexibility in assigning additional readings of particular interest to them.

Since I began teaching development economics in the early 1960s, this relatively new field has matured and changed significantly. Fifteen years ago, economists tended to devote much attention to abstract theories of development. There were several reasons for this, including (1) a natural tendency to try to bring order and simplicity to a new field of inquiry; (2) fascination with the new Keynesian growth theories; (3) lack of data, which restricted the opportunities for empirical research; and (4) limited experience with institutional environments and practical policy issues in a wide range of developing countries. More recently, greater availability of data and improved tools of analysis have stimulated a great deal of empirical research, much of which has caused economists to revise their notions about the development process. In addition, the firsthand experience acquired by many economists, a result of what might be called the "foreign aid boom" of the 1960s, has made them more 
concerned about development policy issues and more aware of the importance of political and other noneconomic factors in the development process.

My own classroom teaching has reflected these broad trends. Particularly since acquiring my own overseas experience, both as an academic researcher and as a government employee and consultant, I have placed less emphasis on theories of development and devoted increasing attention to policy issues and empirical findings. But theory cannot be neglected. Microeconomic theory can be used imaginatively to examine a variety of specific policy issues, and macroeconomic theory is necessary if we are to understand problems such as inflation and balance-ofpayments deficits. I have no regrets, however, about abandoning the search for a comprehensive theory of development, or mentioning only briefly great debates such as the one over "balanced" versus "unbalanced" growth. Writings on these subjects have often been far removed from the arenas in which policy decisions are made. Graduate students in economics should become acquainted with them, but for undergraduates the priorities lie elsewhere.

In summary, I have tried to achieve a balance between theory and policy, leaving space also for historical interpretation, description, and empirical evidence. The analytical tools used are simple, but they do presume an acquaintance with basic macro and micro theory and with the specialized terminology of economics. Ideally, students should also be acquainted with the theory of comparative advantage in international trade, but for those who are not, a brief introduction is provided.

One of the early and great development economists, Nobel prizewinner Gunnar Myrdal, has advised his colleagues to say something about their values in their writings, since nothing is written from a perfectly value-free, or "objective," standpoint. The very choice of topics and relative emphasis given to each, for example, constitutes a value judgment. May I simply say that I share Myrdal's ideals of liberty and equality of opportunity, recognizing with him that these general terms have different policy implications in each country. It follows from this position, I think, that attitudes toward any particular government's development policy should be based not on what kind of hat the chief executive wears, or on what kind of "ism" he, she, or they claim to represent, but rather on what is being done to improve equality of opportunity and the quality of life for all of the country's population.

My opinions about the desirability of certain policy actions and the degree to which various governments have pursued them are expressed in this book only occasionally, and, I hope, without implying that they are the only reasonable opinions possible. The policy discussions in this text strive rather to emphasize the reporting of facts and empirical find- 
ings and a consideration of different viewpoints. A description and interpretation of events is also necessary to provide perspective, and here I strive to report what $I$ think is happening, even if these perceived trends disappoint or displease me. Readers should not assume that I endorse every reported trend. Instead, they should make up their own minds about the merits of alternative policies regarding such issues as tariffs, land ownership, and population growth, based on their own values and an awareness of the implications of each alternative.

Readers may find it difficult to pin a label on me, for I do not claim to represent any particular "ism." These and similar labels have been so abused that they now have little meaning. Too often there is little connection between what a government actually does and what the stereotype of its label says it is doing, and it is the former that should concern us.

This book draws not only on published materials but also on my research and work experience, since 1965, in Argentina, Bolivia, Ecuador, Haiti, and eight island states in the eastern Caribbean. Each of these countries is unique, and outside of the Western Hemisphere the differences among countries are greater still. I am indebted to the participants in the U.S. Department of Labor's 1964 International Manpower Seminar, for which I served as Chief Rapporteur, for introducing me to some of the issues in their twenty-one countries, mainly in Africa and Asia. Without this experience, my selection of examples from outside Latin America and the Caribbean would have been less informed.

In preparing the final manuscript, I have benefited from critical comments by John Adams and several anonymous reviewers. I would also like to thank Jacques Defay for illuminating discussions of the absorptive capacity issue; Elizabeth Erickson for comments on the Physical Quality of Life Index and many stimulating conversations about development issues generally; and Ann Zuvekas for a valuable critical reading of the section on public health. Judith Cromwell deserves much credit for undertaking the typing of the manuscript and executing it so well on top of an already heavy workload. Valuable editorial assistance was provided by Bertrand W. Lummus and Carolyn Eggleston of St. Martin's Press. Finally, I wish to thank my children, Sam and Ann, for their patience.

Clarence Zuvekas, Jr. 


\section{Contents}

\section{Introduction 1}

1

Economic Growth and Economic Development:

Meaning and Measurement 7

What's in a Name? 7

Growth versus Development 8

Not by Economics Alone 11

The Theory of Development and the Development of Theory

Measuring Economic Growth 14

The Widening Income Gap $\quad 17$

Measuring Economic Development 22

Development versus Liberation $\quad 25$

SUMMARY 26

SUGGESTED READINGS 28

2

Economic Obstacles to Growth and Development:

Natural Resource and Capital Contraints $\quad 30$

Climate, Soils, and Terrain $\quad 30$

Industrial Raw Materials 33

Capital and Growth 34

The Vicious Circle of Poverty 39

The Theory of the Big Push 42

SUMMARY 47

SUGGESTED READINGS 48

3

Noneconomic Obstacles to Growth and Development $\quad 49$

Some Alleged Noneconomic Obstacles $\quad 50$

The "Modernization" Controversy 62

Stimulating Change: A Preview of Policy and Strategy Issues 66 
SUMMARY $\quad 71$

SUGGESTED READINGS

71

4

Population Growth and Urbanization $\quad \mathbf{7 4}$

World Population in Historical Perspective 74

Declining Birth Rates in the Demographic Transition

The Geographic Distribution of Population 78

The Arithmetic of Zero Population Growth 82

Population Growth as an Obstacle to Development

Strategies for Slowing Population Growth 89

The Recent Decline in Population Growth Rates 98

Urbanization 101

SUMMARY 105

SUGGESTED READINGS 106

5

International Trade and Economic Development $\quad 108$

The Theory of Comparative Advantage and the Trade-Based

Strategy of Development $\quad 109$

The Comparative Advantage Assumptions: How Realistic? 113

The Terms of Trade 116

Export Price Instability 121

Theories of External Dependence 123

SUMMARY 128

SUGGESTED READINGS 128

6

The Role of Government: Social Overhead Capital 131

Characteristics of Social Overhead Capital 132

Financing Social Overhead Capital Projects 134

Transportation 135

Telecommunications 139

Electric Power 139

Determining Investment Priorities 141

SUMMARY 147

SUGGESTED READINGS $\quad 148$

7

The Role of Government:

Education, Health, and Nutrition 150

Measuring Education and Health as

Dimensions of Well-Being 151 
Education 154

Health 162

Nutrition $\quad 170$

SUMMARY 179

SUGGESTED READINGS 180

8

The Role of Government: Economic Planning 182

Development Planning: Meaning and Origins 183

Comprehensive Macroeconomic Planning $\quad 185$

Manpower Planning $\quad 195$

Regional Planning 197

Sector Planning 199

Project Planning 200

SUMMARY 201

SUGGESTED READINGS 201

9

Agriculture and Rural Development 203

The Role of Agriculture in Economic Growth and Development 204

Trends in World Food Production 207

Overcoming Obstacles to Agricultural Development $\quad 210$

SUMMARY 238

SUGGESTED READINGS 239

10

Industrialization $\quad 242$

Stages in the Process of Industrialization $\quad 243$

Import Substitution 245

Export-Oriented Industrialization 250

Recent Trends in Industrial Output 252

Overcoming the Obstacles to More Rapid

Industrial Development 255

Intermediate Technology 259

Industrial Location Policy 261

SUMMARY 263

SUGGESTED READINGS 264

11

Income Distribution 266

The Distribution of Income among Nations $\quad 267$ 
Income Inequality within Nations and Its Relationship with Economic Growth 268

Does Inequality Stimulate Growth? 268

Explaining Widening Income Inequalities within

Developing Countries 271

Measuring Income Distribution within Countries:

The Problem of Defining Income 272

Alternative Measures of Income Inequality 276

Income Redistribution Policies 287

SUMMARY 292

SUGGESTED READINGS 293

12

Employment 295

The Structure of Employment in Developing Countries

Unemployment and Underemployment Estimates $\quad 297$

Unemployment and Underemployment as

Welfare Indicators $\quad 300$

Measuring Rural Underemployment: A Case Study 303

Growth and Employment 306

The Employment Potential of Manufacturing 307

Policies for Increasing Rural Employment $\quad 310$

SUMMARY 313

SUGGESTED READINGS $\quad 314$

13

Financing Development: Mobilizing Domestic Savings

The Savings Capacity of Developing Countries $\quad 317$

Recent Trends in Domestic and Foreign Savings $\quad 318$

The Structure of Domestic Savings 320

Mobilization of Private Savings: The "Financial

Liberalization" Approach 321

Mobilizing Private Savings: Other Government Actions 326

Taxation $\quad 329$

Consumption as Investment (Savings) 332

SUMMARY 333

SUGGESTED READINGS 333

\section{4}

Financing Development: Foreign Aid and Private

Foreign Investment

335

Foreign Aid 336 
Private Foreign Investment $\quad 356$

SUMMARY 363

SUGGESTED READINGS $\quad 364$

15

Reforms in the Structure of International Trade

and Finance 366

Regional Economic Integration 367

UNCTAD 371

Commodity Agreements and Producer Cartels 372

Tariff Preferences 377

Nontariff Barriers to Trade $\quad 379$

Regulations Governing Technology Transfer $\quad 379$

Assessing the Effectiveness of Trade-Oriented

Growth Strategies $\quad 380$

Increased Balance-of-Payments Assistance from the IMF 382

SUMMARY AND OUTLOOK 386

SUGGESTED READINGS $\quad 387$

16

The New Issues: Limits to Growth, Energy, the Environment, and the Changing International Economic Order 388

The Limits to Growth 389

The Second Club of Rome Study 392

Solving the Food and Population Problems:

Three Questionable Strategies 394

The Energy Crisis and the Developing Countries $\quad 399$

The Destruction of Food Supply Capability $\quad 400$

A New International Order 404

A CONCLUDING NOTE 409

SUGGESTED READINGS 410

Index 413 